\title{
'Trendy' Cities: Exploring the Adoption of Different Types of Social Media by Portuguese Municipalities
}

\author{
Tiago Silva $^{1}(\mathbb{D})$, António $\operatorname{Tavares}^{2}$ (D), and Mariana Lameiras ${ }^{3(\square)}(\mathbb{D}$ \\ ${ }^{1}$ Institute of Social Sciences, University of Lisbon (ICS-ULisboa), \\ Lisbon, Portugal \\ Tiago.Silva@eui.eu \\ ${ }^{2}$ United Nations University Operating Unit on Policy-Driven Electronic \\ Governance (UNU-EGOV), Research Center in Political Science, \\ University of Minho, Braga, Portugal \\ atavares@eeg.uminho.pt \\ ${ }^{3}$ United Nations University Operating Unit on Policy-Driven Electronic \\ Governance (UNU-EGOV), Communication and Society Research Center \\ (CSRC), University of Minho, Braga, Portugal \\ lameiras@unu.edu
}

\begin{abstract}
What are the determinants of social media adoption by local government? This ongoing research provides a tentative answer to this question by analysing the 308 municipalities in Portugal. Extending previous analyses of Facebook and/or Twitter usage levels, we examine why local governments adopt a particular social media platform. More concretely, we explore, with statistical analyses, the determinants of the adoption of different types of social media. We investigate the adoption of three extremely popular social media (i.e. Facebook, Twitter and YouTube) as well as possible alternatives to those, more popular, applications. Since these platforms have distinct natures and can serve diverse purposes, we examine to what extent aspects such as local government's commitment to transparency and participation, administrative capacity, media landscape, and socio-demographic and economic factors can explain the adoption of certain social media platforms. The results show that, indeed, demographic characteristics and administrative capacity are important factors for the adoption of less popular social media. Surprisingly, we also observe a geographical difference in municipalities' social media adoption, with the south, in this regard, being 'trendier', or more innovative, than the north.
\end{abstract}

Keywords: Local government $\cdot$ Social media $\cdot$ Transparency $\cdot$ E-Participation

\section{Introduction and Short Literature Review}

Recently, much has been written in academia about social media. Undoubtedly, these inexpensive and user-friendly online platforms became extremely popular and widely used around the world. With billions of users worldwide, we live in a post mass media society where a large part of the population relies on those online applications to get 
information [1]. Naturally, the popularity of social media has also captured the attention of public administration and different levels of government.

By allowing their users to generate and share original content within very large, and relatively diverse, networks, social media have opened the door to real-time interaction between public sector officials and citizens [2]. Understandably, this has brought some expectations to improve public administration, different levels and sectors of government and, more broadly, democracy as well. Amid reports of a steady increase, in the last decades, of citizens' discontent with democratic institutions [3, 4], it seems that social media can play an important role in the future of our societies by promoting, together with other ICTs, a culture of receptiveness and transparency in public organizations and political institutions [5]. Indeed, under certain conditions, the Internet and social media can contribute positively to political participation [6], even though, despite this recognized capacity, they can as well lead to the exact opposite effect [7]. In the end, this perceived potential of social media to mitigate important challenges in established democracies make the study of the adoption and usage of those platforms by political and public organizations extremely relevant. In this paper we focus on social media use by local government.

Regardless of the reasons behind their adoption and use (i.e. either simply to inform or to promote citizens' interaction, participation and collaboration), a large number of local governments are nowadays incorporating social media in their communication repertoire [8]. The study of local government use of social media has been mainly focusing on frequency of use (e.g. post count) and levels of citizen's engagement with the messages [9]. Much less attention has been paid to (a) what are the types of social media adopted by the municipalities and (b) the communication strategies of the municipalities for those platforms. This paper addresses precisely those two untapped aspects of social media use by local governments, offering an empirical contribution to the former and providing an initial discussion and hypotheses for the latter.

There are two fundamental assumptions, or social media aspects, guiding this study. The first one is that there is a great amount of uncertainty in both using and adopting those platforms. Regarding their use, differently from mainstream media, the reach and impact of the content generated on social media is extremely uncertain. As Castells [10] nicely puts it, communication on social media is like casting a message in a bottle into the ocean. Any message can either go viral or unnoticed in the massive ocean of information called cyberspace. In other words, institutions cannot fully control the visibility and impact of their online communication. The uncertainty in the adoption of social media concerns the fact that institutions have an extremely vast and growing catalogue to 'choose' from. It is difficult to foresee which applications will become popular and persevere and which ones will abruptly end. For this reason, institutions must choose carefully those applications, especially since "being active" is a key requirement for their success [11].

The second important aspect of social media is that those online applications can be quite distinct. In fact, the only common aspect shared by all of them is the fact that, differently from Internet forums, they are structured or built around people rather than topics [12]. However, they can be public, semi-private or private, and they differ regarding the type of content that they allow its users to generate and share. Depending on the type of content allowed on those platforms, the costs of adopting a particular 
social media will vary as well (i.e. sharing original text/photo is easier/cheaper than sharing original video). As a consequence, not only the users of those platforms vary considerably, in terms of volume and characteristics, but also, partially as a consequence of that, social media can be used in different ways and for different purposes. It is normal for institutional actors to give different uses to different social media [13].

Overall, besides focusing on usage levels, it is important to take a step back and understand why municipalities adopt a particular type of social media. While there are relevant benefits from using them, the risks associated with their use are equally important. The goal of this paper is precisely to explore what factors explain the adoption of a particular social media by the Portuguese local governments.

\section{Research Question, Hypotheses and Methodology}

This paper's research question is: What are the determinants of social media adoption by the Portuguese local governments? Even though our main research hypotheses derive from the literature, this study, at this stage, has a strong exploratory component. We investigate this research question by looking at three of the most internationally popular social media: Facebook, Twitter and YouTube. Our three dependent variables are dichotomous measures for whether a municipality has a Facebook, Twitter, and YouTube account $(1=$ Yes $)$. Additionally, a fourth dependent variable is included to assess the presence of municipalities in alternative social media platforms besides those three main ones (e.g. Flickr, Google+, etc.) $(1$ = Yes). All variables refer to 2016.

Concerning our research hypotheses and independent variables, the use of social media by different organizations is often associated with efforts to increase both transparency and citizens' participation and collaboration with those organizations, since it allows dialogic communication [14]. Indeed, studies have found a positive relationship between social media usage levels and the municipalities' commitment to transparency $[8,9]$. We therefore expect those two motivations to be associated with the adoption of different social media. More concretely, we expect that:

(H1) Municipalities with higher commitment to participation are more likely to be present on social media.

(H2) Municipalities with higher commitment to transparency are more likely to be present on social media.

In this study we have two variables measuring the municipalities' commitment to participation and transparency. The former is measured by a dummy variable called "Participation" coded " 1 " if the municipality has been conducting participatory budgeting initiatives and " 0 " otherwise. Commitment to local government transparency is measured with an index, ranging from 0 to 100 , based on an assessment of the information provided in municipalities' websites [15].

Even though creating a social media account is an easy and, usually, costless process, being active (and original) on them, which is a crucial aspect for the success of the online communication of any organization, is not as easy or straightforward. An effective use of 
social media requires the allocation of important resources. In fact, lack of resources can be a factor hindering local governments' use of those platforms [16, 17]. This factor is particularly important in the case of less popular social media, with higher cost/benefit, and the ones that only allow more elaborated/costly content (e.g. YouTube). Therefore, we expect that:

(H3) Municipalities with higher administrative/economic capacity are more likely to adopt social media, particularly the less popular or costlier ones.

Administrative capacity is measured with two different variables. The first one is the number of local government employees. The second is the proportion of own revenues raised by the municipalities.

Two other aspects examined in this study are the political setting and the media landscape of the Portuguese municipalities. Concerning the first one, we expect political participation and political competition to have an effect on municipalities' adoption of social media. Citizens' use of social media and political behavior should be positively correlated [18] and political competition should also affect positively governments' commitment to transparency and disclosure of information [19-21]. For this reason, we expect that:

(H4) The higher the level of political participation and political competitiveness, the more likely municipalities will be to adopt different social media platforms.

Political participation is measured by the average turnout in the last three local elections. Similarly, political competitiveness is the average margin of victory (i.e. the difference, in percentage points, between the two first candidates/parties) in the last three mayoral elections. We use an average of three elections in order to capture longlasting trends of these two variables.

Regarding media landscape, we employ the number of local radios and newspapers in the municipality. The goal is to explore a possible relationship between the local media environment and the use of social media. We expect that local governments might rely more on different social media when the number of local media outlets is lower.

Finally, we include a set of control variables in the estimations: population size, level of education, number of parishes, proportion of foreign population, purchase power and latitude.

\section{Results}

Concerning the adoption of different social media by the Portuguese municipalities, our analysis shows that Facebook is, by far, the most popular social media platform. As displayed in Table 1, 85\% of all Portuguese municipalities had, in 2016, an official Facebook account. The second most popular Social Networking Site (SNS) was YouTube. More than half of the Portuguese municipalities had an account in this platform. With respect to Twitter, only $36 \%$ of the municipalities used this platform. Finally, around $33 \%$ of the 308 Portuguese municipalities had accounts in some other social media applications that were not one of the three majors (e.g. Google+, Flickr). 
Table 1. Descriptive statistics of the variables.

\begin{tabular}{l|l|l|l|l}
\hline & Mean & Sd & Min & Max \\
\hline Facebook & 0.851 & 0.357 & 0 & 1 \\
\hline Twitter & 0.357 & 0.480 & 0 & 1 \\
\hline YouTube & 0.523 & 0.500 & 0 & 1 \\
\hline Other Social Networking Sites (SNS) & 0.331 & 0.471 & 0 & 1 \\
\hline Participation & 0.338 & 0.474 & 0 & 1 \\
\hline Transparency & 44.30 & 17.21 & 0.82 & 94.23 \\
\hline \#Employees & 385.0 & 580.7 & 27 & 7417 \\
\hline Own revenues & 39.01 & 18.33 & 2.31 & 90.21 \\
\hline Political participation & 62.86 & 6.39 & 44.86 & 79.13 \\
\hline Political competition & 27.85 & 7.77 & 10.99 & 49.16 \\
\hline Latitude & 39.60 & 1.86 & 32.65 & 42.11 \\
\hline \#Parishes & 10.04 & 8.51 & 1 & 61 \\
\hline Population (log) & 9.70 & 1.14 & 6.11 & 13.21 \\
\hline Education & 9.944 & 4.554 & 2.87 & 33.55 \\
\hline Foreign Pop. & 2.677 & 2.829 & 0.31 & 21.63 \\
\hline Purchase Power & 80.55 & 18.15 & 56.54 & 207.9 \\
\hline Local Media & 3.640 & 5.019 & 0 & 49 \\
\hline
\end{tabular}

The results of the logistic regression analyses are presented in Table 2. Odds ratios (OR) and robust standard errors (in parentheses) are reported. OR higher than one indicate a positive relationship between the variables. Contrarily, OR lower than 1 imply a negative relationship between variables. The only difference between the four models is the dependent variable.

The first model investigates the adoption of Facebook. Since a large number of municipalities have adopted this platform, nothing very relevant can be taken or interpreted from these results. The only variable that is statistically significant is Latitude (with an OR lower than 1), which measures the geographical location of the municipality in the country (more north or south). The results suggest that municipalities from the north are less likely than the ones in the south to have a Facebook account. Overall, we can just say that Facebook is widely popular among Portuguese municipalities.

The results become far more interesting when we look at the other, less popular, social media Sites. In the case of Twitter, five variables display statistical significance. Again, municipalities from the south are more likely to use Twitter. Indeed, this was a consistent finding across all dependent variables, suggesting that municipalities from the north of Portugal are less likely to adopt social media compared to their southern counterparts. In addition to that, the results show that municipalities more committed to participation initiatives (i.e. with participatory budgeting) are almost twice as likely as the others to have a Twitter account. Besides that, municipalities with a higher number of parishes (sub-municipal governments/districts), with more economic resources and more employees are also more likely to be present on Twitter. Overall, our analysis 
shows that Twitter is not a popular platform among Portuguese local governments and that its adoption is positively associated with the municipalities' resources and commitment to engage with the citizens. However, it is also possible that the use of Twitter is not a direct consequence of municipalities wanting to engage citizens but rather a consequence of their efforts to get more visibility to specific e-participation initiatives.

Table 2. Logistic regression analysis of the determinants of social media adoption by the 308 Portuguese Municipalities.

\begin{tabular}{|c|c|c|c|c|}
\hline & $\begin{array}{l}\text { (1) } \\
\text { Facebook }\end{array}$ & $\begin{array}{l}\text { (2) } \\
\text { Twitter }\end{array}$ & $\begin{array}{l}\text { (3) } \\
\text { YouTube }\end{array}$ & $\begin{array}{l}\text { (4) } \\
\text { Alternative SNS }\end{array}$ \\
\hline Participation & $\begin{array}{l}1.000 \\
(0.381)\end{array}$ & $\begin{array}{l}1.970 * * \\
(0.549)\end{array}$ & $\begin{array}{l}1.087 \\
(0.301)\end{array}$ & $\begin{array}{l}1.719 * \\
(0.491)\end{array}$ \\
\hline Transp. & $\begin{array}{l}1.016 \\
(0.0106)\end{array}$ & $\begin{array}{l}1.010 \\
(0.00808)\end{array}$ & $\begin{array}{l}1.006 \\
(0.00785)\end{array}$ & $\begin{array}{l}1.000 \\
(0.00855)\end{array}$ \\
\hline Parishes & $\begin{array}{l}1.031 \\
(0.0267)\end{array}$ & $\begin{array}{l}1.062 * * * \\
(0.0244)\end{array}$ & $\begin{array}{l}1.071 * * \\
(0.0306)\end{array}$ & $\begin{array}{l}1.043 * \\
(0.0248)\end{array}$ \\
\hline Pop. (log) & $\begin{array}{l}1.168 \\
(0.448)\end{array}$ & $\begin{array}{l}0.639 \\
(0.206)\end{array}$ & $\begin{array}{l}0.340 * * * \\
(0.111)\end{array}$ & $\begin{array}{l}0.556^{*} \\
(0.178)\end{array}$ \\
\hline Education & $\begin{array}{l}1.000 \\
(0.0835)\end{array}$ & $\begin{array}{l}0.950 \\
(0.0625)\end{array}$ & $\begin{array}{l}0.979 \\
(0.0668)\end{array}$ & $\begin{array}{l}0.969 \\
(0.0625)\end{array}$ \\
\hline Foreign Pop. & $\begin{array}{l}0.908 \\
(0.0716)\end{array}$ & $\begin{array}{l}0.961 \\
(0.0653)\end{array}$ & $\begin{array}{l}0.975 \\
(0.0715)\end{array}$ & $\begin{array}{l}0.849 * * \\
(0.0574)\end{array}$ \\
\hline Purchase P. & $\begin{array}{l}1.013 \\
(0.0227)\end{array}$ & $\begin{array}{l}0.991 \\
(0.0173)\end{array}$ & $\begin{array}{l}1.004 \\
(0.0175)\end{array}$ & $\begin{array}{l}1.004 \\
(0.0166)\end{array}$ \\
\hline Local Media & $\begin{array}{l}0.965 \\
(0.0484)\end{array}$ & $\begin{array}{l}0.972 \\
(0.0720)\end{array}$ & $\begin{array}{l}0.981 \\
(0.0453)\end{array}$ & $\begin{array}{l}0.900 * * \\
(0.0470)\end{array}$ \\
\hline Employees & $\begin{array}{l}1.000 \\
(0.000830)\end{array}$ & $\begin{array}{l}1.001 * * \\
(0.000605)\end{array}$ & $\begin{array}{l}1.003 * * * \\
(0.00106)\end{array}$ & $\begin{array}{l}1.002 * * * \\
(0.000606)\end{array}$ \\
\hline Revenues R. & $\begin{array}{l}1.010 \\
(0.0193)\end{array}$ & $\begin{array}{l}1.042 * * \\
(0.0182)\end{array}$ & $\begin{array}{l}1.040 * * \\
(0.0177)\end{array}$ & $\begin{array}{l}1.044 * * * \\
(0.0165)\end{array}$ \\
\hline Turnout & $\begin{array}{l}0.993 \\
(0.0371)\end{array}$ & $\begin{array}{l}1.008 \\
(0.0302)\end{array}$ & $\begin{array}{l}0.978 \\
(0.0283)\end{array}$ & $\begin{array}{l}0.976 \\
(0.0289)\end{array}$ \\
\hline Margin of $\mathrm{V}$ & $\begin{array}{l}1.030 \\
(0.0252)\end{array}$ & $\begin{array}{l}1.001 \\
(0.0200)\end{array}$ & $\begin{array}{l}1.011 \\
(0.0188)\end{array}$ & $\begin{array}{l}1.006 \\
(0.0206)\end{array}$ \\
\hline Latitude & $\begin{array}{l}0.724 * * * \\
(0.0886)\end{array}$ & $\begin{array}{l}0.829 * * \\
(0.0705)\end{array}$ & $\begin{array}{l}0.838^{* *} \\
(0.0688)\end{array}$ & $\begin{array}{l}0.785 * * * \\
(0.0636)\end{array}$ \\
\hline Constant & $\begin{array}{l}48,883 \\
(330,488)\end{array}$ & $\begin{array}{l}5,555^{*} \\
(28,142)\end{array}$ & $\begin{array}{l}3.629 \mathrm{e}+06^{* * *} \\
(1.892 \mathrm{e}+07)\end{array}$ & $\begin{array}{l}888,589 * * * \\
(4.545 \mathrm{e}+06)\end{array}$ \\
\hline Obs. & 308 & 308 & 308 & 308 \\
\hline Pseudo R2 & 0.0844 & 0.103 & 0.121 & 0.105 \\
\hline
\end{tabular}

The results for YouTube are similar to the ones we found for Twitter. There are only two exceptions. The first one is that the difference in "Participation" is not statistically significant. The second one is that population size becomes statistically 
significant with a negative coefficient. This means that municipalities with larger populations are less likely to adopt YouTube. Overall, these results further confirm that, when it comes to the adoption of social media, human and financial resources are important for municipalities to venture on alternatives to Facebook. Indeed, we can say that having less resources hinders local governments from being present on less popular social media.

Finally, when it comes to alternative social media, we also get very interesting results. The first one is that "Participation" is significant. The municipalities with Participatory Budgeting initiatives are about $70 \%$ more likely to have an account in one alternative (less popular) social media. Again, it might be the case that rather than using them to interact with citizens, municipalities are simply trying to expand their online communication channels to give more visibility to those initiatives.

The municipalities' resources are an important factor to explain presence in alternative SNS. The number of parishes, population size, the percentage of foreigners and latitude are also statistically significant. In the case of population, foreign population and latitude, their OR is lower than 1, meaning that the relationship between the variables is negative. However, what is perhaps more interesting in this last model is the statistically significant and negative relationship between local media and the adoption of alternative social media. To put it in other words, municipalities with a higher number of local radio stations and newspapers are less likely to adopt alternative (less popular) social media. This suggests that perhaps Portuguese local governments rely on social media to circumvent some limitations (or lack of traditional alternatives) to inform their citizens.

\section{Conclusion}

There are important limitations in this paper due to the fact that it is an ongoing research. In specific, the nature of our dependent variables does not allow us to explore short-term factors such as the characteristics of mayors and executives and the institutional configuration of communication departments inside municipalities. These are factors that indubitably might play an important role in the adoption of different social media and that allow an in-depth study of the determinants of social media adoption by Portuguese local governments. Therefore, we exclusively focus on long-term, less mutable, variables. Nevertheless, our study revealed important aspects regarding the adoption of those platforms by local government and provides grounded clues for further research and methodology.

Perhaps the most important, or at least consistent, finding of this study was that resources and local government capacity matter. And they seem to matter a lot. That was the only hypothesis (H3) that the quantitative analysis fully confirmed. We knew already, from previous studies, that resources matter for usage levels (i.e. municipalities with more resources are more active on social media [9]). Now we also know that these are important factors for the adoption of less popular social media. Contrarily, political aspects (turnout and competition) (H4) do not seem to affect the adoption of those platforms. Overall, this study suggests that Portuguese municipalities are indeed aware of the risks involved in adopting social media. They are more likely to adopt more 
alternative platforms when they have resources to guarantee their successful use (i.e. being active on them).

We also found that while commitment to transparency does not have any impact on social media adoption, municipalities that have participatory budgeting initiatives are more likely to have accounts on alternative, less popular platforms. We can, however, interpret this result in two different ways. It can indeed be that these alternative SNS are more suitable to engage citizens, since there is an understanding that Twitter is more suitable for sharing ideas while Facebook is used for leisure or networking. However, it can also be that these municipalities are simply using a larger variety of online applications to promote their participatory budgeting initiatives. Further analyses must be conducted to better investigate these two hypotheses. This is, indeed, the next step of this project that aims, with a multi-method approach, to better understand the use of social media by local government.

One final aspect worth mentioning is that we found that municipalities from the north of Portugal tend to be more conservative when it comes to social media adoption, a difference observed even for the most popular application - Facebook. This is interesting since the north is also more conservative when it comes to local politics and the importance of religion. When it comes to the adoption of new communication channels, we can say that southern municipalities seem to be trendier than their counterparts in the north.

Acknowledgments. This paper is a result of the project "SmartEGOV: Harnessing EGOV for Smart Governance (Foundations, methods, Tools)/NORTE-01-0145-FEDER-000037", supported by Norte Portugal Regional Operational Programme (NORTE 2020), under the PORTUGAL 2020 Partnership Agreement, through the European Regional Development Fund (EFDR). António Tavares acknowledges the financial support of the Portuguese Foundation for Science and Technology and the Portuguese Ministry of Education and Science through national funds [Grant No. UID/CPO/0758/2019].

\section{References}

1. Gottfried, J., Shearer, E.: News Use Across social medial Platforms 2016. Pew Research Center (2018)

2. Rybalko, S., Seltzer, T.: Dialogic communication in 140 characters or less: how fortune 500 companies engage stakeholders using Twitter. Public Relat. Rev. 36(4), 336-341 (2010)

3. Dalton, R.J.: Citizen Politics: Public Opinion and Political Parties in Advanced Industrial Democracies. Chatham House Press, New York (2002)

4. Flickinger, R.S., Studlar, D.T.: The disappearing voters? Exploring declining turnout in Western European elections. West Eur. Polit. 15(2), 1-16 (1992)

5. Bertot, J.C., Jaeger, P.T., Grimes, J.M.: Using ICTs to create a culture of transparency: e-government and social media as openness and anti-corruption tools for societies. Gov. Inf. Q. 27(3), 264-271 (2010)

6. Bakker, T.P., De Vreese, C.H.: Good news for the future? Young people, Internet use, and political participation. Commun. Res. 38(4), 451-470 (2011)

7. Kent, M.L.: Using social media dialogically: public relations role in reviving democracy. Public Relat. Rev. 39(4), 337-345 (2013) 
8. Bonsón, E., Torres, L., Royo, S., Flores, F.: Local e-government 2.0: social media and corporate transparency in municipalities. Gov. Inf. Q. 29(2), 123-132 (2012)

9. Lameiras, M., Silva, T., Tavares, A.: An empirical analysis of social media usage by local governments in Portugal. In: Proceedings of the 11th International Conference on Theory and Practice of Electronic Governance, pp. 257-268. ACM (2018)

10. Castells, M.: Communication Power. OUP, Oxford (2013)

11. Kaplan, A.M., Haenlein, M.: Users of the world, unite! The challenges and opportunities of social media. Bus. Horiz. 53(1), 59-68 (2010)

12. Boyd, D.M., Ellison, N.B.: Social network sites: definition, history, and scholarship. J. Comput.-mediated Commun. 13(1), 210-230 (2007)

13. Morini, M.: Twitter for politics and Facebook for Leisure? The social media behaviour of Italian Politicians. Malaysian J. Media Stud. 17(1), 58-69 (2015)

14. Linders, D.: From e-government to we-government: defining a typology for citizen coproduction in the age of social media. Gov. Inf. Q. 29(4), 446-454 (2012)

15. da Cruz, N.F., Tavares, A.F., Marques, R.C., Jorge, S., de Sousa, L.: Measuring local government transparency. Public Manag. Rev. 18(6), 866-893 (2016)

16. Omar, K., Stockdale, R., Scheepers, H.: Social media use in local government: an Australian perspective. Int. J. Public Adm. 37(10), 666-675 (2014)

17. Moon, M.J.: The evolution of e-government among municipalities: rhetoric or reality? Public Adm. Rev. 62(4), 424-433 (2002)

18. Gil de Zúñiga, H., Jung, N., Valenzuela, S.: Social media use for news and individuals' social capital, civic engagement and political participation. J. Comput. Commun. 17(3), 319-336 (2012)

19. Tavares, A.F., da Cruz, N.F.: Explaining the transparency of local government websites through a political market framework. Gov. Inf. Q. Forthcom. 1-13 (2017)

20. Gandía, J.L., Archidona, M.C.: Determinants of web site information by Spanish city councils. Online Inf. Rev. 32(1), 35-57 (2008)

21. García, A.C., García-García, J.: Determinants of online reporting of accounting information by Spanish local government authorities. Local Gov. Stud. 36(5), 679-695 (2010) 